University of Wollongong

Research Online

Faculty of Social Sciences - Papers (Archive) Faculty of Arts, Social Sciences \& Humanities

$1-1-2016$

Assembling urban regeneration? Resourcing critical generative accounts of urban regeneration through assemblage

Pauline M. McGuirk

University of Newcastle, pmcguirk@uow.edu.au

Kathy Mee

University of Newcastle

Kristian J. Ruming

Macquarie University

Follow this and additional works at: https://ro.uow.edu.au/sspapers

Part of the Education Commons, and the Social and Behavioral Sciences Commons

Research Online is the open access institutional repository for the University of Wollongong. For further information contact the UOW Library: research-pubs@uow.edu.au 


\title{
Assembling urban regeneration? Resourcing critical generative accounts of urban regeneration through assemblage
}

\author{
Abstract \\ In critical urban studies, managed urban regeneration has been linked to trajectories of neo-liberalising \\ urban policy and urban entrepreneurialism. While the insights arising from this work have been many and \\ valuable, significant gaps remain particularly in terms of the foci of analysis and the conception of \\ politics. In this paper, we aim to address these gaps and to reposition the conceptualization of \\ regeneration as a performed and emergent consequence of 'relatedness' and as subject to a range of \\ relational effects and determinations. To do so we work through four capacities of assemblage thinking \\ that are particularly productive for this task: (i) revealing the relational, multiple and processual nature of \\ urban trajectories; (ii) revealing the multi-scalar labouring involved in configuring the (socio-material) \\ assemblages that constitute regeneration; (iii) identifying openings for multiple possible trajectories of \\ regeneration; (iv) providing critical insights into how regeneration trajectories are constrained. We \\ conclude with reflections on what assemblage thinking offers in terms of critically and generatively \\ rethinking urban regeneration.
}

\section{Keywords}

resourcing, regeneration, assemblage, accounts, generative, urban, critical, assembling

Disciplines

Education | Social and Behavioral Sciences

\section{Publication Details}

McGuirk, P. M., Mee, K. J. \& Ruming, K. J. (2016). Assembling urban regeneration? Resourcing critical generative accounts of urban regeneration through assemblage. Geography Compass, 10 (3), 128-141. 
1 Assembling urban regeneration? Resourcing critical generative accounts of urban regeneration through assemblage.

2016 Geography Compass, 10, 128-41

6

7

\section{M드oirk PM}

Discipline of Geography and Environmental Studies, School of Environmental and Life Sciences, University of Newcastle, NSW 2308, Australia

Email: Pauline.mcguirk@newcastle.edu.au

\section{Mee KJ}

Discipline of Geography and Environmental Studies, School of Environmental and Life Sciences, University of Newcastle, NSW 2308, Australia

Email: kathy.mee@newcastle.edu.au

\section{Ruming KJ}

Department of Geography and Planning, Macquarie University, NSW 2109, Australia Email: kristian.ruming@mq.edu.au

Abstract: In critical urban studies, managed urban regeneration has been linked to trajectories of neoliberalising urban policy and urban entrepreneurialism. While the insights arising from this work have been many and valuable, significant gaps remain particularly in terms of the foci of analysis and the conception of politics. In this paper we aim to address these gaps and to reposition the conceptualization of regeneration as a performed and emergent consequence of 'relatedness' and as subject to a range of relational effects and determinations. To do so we work through four capacities of assemblage thinking that are particularly productive for this task: (i) revealing the relational, multiple and processual nature of urban trajectories; (ii) revealing the multiscalar labouring involved in configuring the (socio-material) assemblages that constitute regeneration; (iii) identifying openings for multiple possible trajectories of regeneration; (iv) providing critical insights into how regeneration trajectories are constrained. We conclude with reflections on what assemblage thinking offers in terms of critically and generatively rethinking urban regeneration. 


\section{Introduction}

38 Urban regeneration projects are well-established in the repertoire of state responses to deindustrialization, urban-economic restructuring and the perceived need to 'glurbanise' cities ( $M^{\complement}$ Guirk 2004). Critical urban geography has yielded powerful analyses and searing critiques of the processes and distributional effects of managed urban regeneration, linking it to trajectories of neoliberalising urban policy, urban entrepreneurialism and the competitivization of urban development (Hall and Hubbard 1998; Brenner and Theodore 2002; Ponzini and Rossi 2010; Samara 2010; Rossi and Vanolo 2013). The insights arising from this work have been many and valuable. Yet significant gaps remain, particularly in the foci of analysis and the conception of politics.

Much critical analysis has focused on formal policy mechanisms, integrated masterplanned regeneration strategies, megaprojects and their constitutive political alliances ( $O^{\prime}$ Callaghan 2012). Relatedly, it has worked with a conception of the agents, relations and processes that constitute regeneration that, we argue, can be productively expanded to further critical and generative effect. Methodologically, much regeneration research has emphasised policy review and discourse analysis over the practice-oriented or ethnographic. Consequently, it has been tempted to read off the aspirations of policy and strategy documents as if they have pre-scripted effects on interest-formation, agency and power, related identifications and subjectifications (see Jacobs 2012). Critical accounts have also tended to focus on actors perceived to be in politically and economically authoritative positions and on groups resisting these authorities, downplaying the place of public servants, residents and other actors in the everyday enactment of regeneration, whilst giving little attention to the agentic capacities of the material or other non-human entities. Finally, regeneration politics are often read through the prism of neoliberal urbanism with insufficient attention to their unfolding in and through grounded 'frictions' in response to particular problematisations, and in light of the accommodations and negotiations that arise in situ from these (Tsing 2011). In short, too little attention has been paid to how practices interact with formal tools of regeneration and how these local practices articulate with 'wider processes' (Farber 2014). Seeing politics through the prism of antagonistic struggle against neoliberalisation has, in turn, limited attention to the politics of negotiation around regeneration's everyday 
practice and the various settlements this involves, including in sites outside "antagonistic constellations" (Farber 2014, 121).

So significant scope for expanding the registers through which urban regeneration is understood, the array of constitutive actors, objects and practices and their relational character, the conception of politics and the multiple sites of political negotiation underpinning regeneration (Fuller 2013). Some critical analyses have begun to explore these expansions (see Ward 2011; Lees 2012; O'Callaghan 2012; Brownhill 2013; Lagendijk et al 2014). In this paper, we build on this work to analyse how assemblage theory can inform an expansive reconceptualization of regeneration to reposition it as a performed, emergent and diversely-constituted practice, enacted in the socio-material 'frictions' and negotiations of the everyday. By urban regeneration we refer to area-based interventions-often publicly funded or supported-aimed at producing ongoing improvements in the social, economic and physical conditions of places and communities experiencing aspects of decline (adapted from Leary and McCarty, 2013, 9) ${ }^{1}$. Following Lagendijk et al (2014) we approach urban regeneration as an open conception, without assuming pre-defined prepositions about actors, roles, practices, materials or mechanisms but regarding it as assemblage of processes centred on producing the above-mentioned improvements.

We draw on an assemblage approach to envisage regeneration as a gathering of heterogeneous elements, consistently drawn together as an identifiable terrain of action and debate (Li 2007, 266). This, we argue, builds a relational and multiplex conception of regeneration as subject to a range of relational effects and determinations, rather than a strategic project driven by institutional design from authoritative bodies (Allen and Cochrane, 2007). Further, this conception opens out the points of political intervention, allowing regeneration's often naturalized hierarchies and hegemonic power relations to be unsettled such that more generative capacities and trajectories might be revealed and activated.

\footnotetext{
${ }^{1}$ Gentrification has come to map closely onto urban regeneration, particularly in its state-led, new-build varieties (Cochrane 2007). Other state-led modalities, many associated with gentrification effects, include waterfront and brownfield redevelopment, mixed-used precincts, investments in public space and infrastructures, cultural investments, and community-led regeneration (see Leary and McCarty 2013).
} 
The paper explores what an assemblage lens offers in terms of critically and generatively rethinking urban regeneration. We explore how assemblage thinking can unpack how regeneration is made and how its being made differently might become a possibility, such that inherited understandings of what constitutes regeneration can be enlarged. Nonetheless, we remain sensitive to the materialisations of socio-economic processes that embed any regeneration process (Swanton 2013). We aim to unsettle taken-for-granted meanings of regeneration, recognize the obdurate relations and materialities that stabilize particular regeneration patterns, yet also suggest analyses that might destabilize dominant framings to reveal more fully its constitutive processes and practices (Müller 2015a). We begin by outlining what assemblage brings to understandings of the urban, before presenting a short vignette drawing from our assemblage-informed research on urban regeneration in Newcastle, NSW, Australia. We then detail four capacities of assemblage thinking that are particularly productive for the critical and generative rethinking regeneration we seek to advance through this work. We conclude by drawing out the political capacity of assemblage for urban regeneration scholarship.

\section{Thinking the urban through assemblage}

114 Assemblage thinking has a growing influence across urban studies as analysts appreciate its 115 "highly developed sense of urban complexity, of the unities and disunities of the stabilities 116 and instabilities and especially the complex and heterogeneous networks of connection and 117 association out of which the city as a social and as a physical entity is formed and sustained" 118 (Bender 2010, 317; and see Dovey 2010, McCann and Ward 2011, Acuto 2011, Brownhill 119 2013, Farber 2014; Lagendijk et al 2014). Assemblage's relational ontology understands the 120 urban as constituted by constellations of elements configured into dynamic arrangements of 121 relations and composed into "some form of provisional socio-spatial formation" (Anderson 122 and McFarlane 2012, 124). These formations' appearance as well-ordered and stabilized is a 123 product of the sedimentation and territorialisation of order across heterogenous social and 124 material elements and practices (Legg 2009). Cities are viewed not so much as structured 125 and settled, but as being provisionally assembled as 'an assemblage of assemblages' (Dovey 126 2010; Farías 2011). Despite their seemingly enduring nature, cities and their constitutive 127 processes of re/composition are "alive and brimming with movements, practices, 128 performances and contingencies" (Smith 2003, 38). The city's multiple assemblages are 
conceived as socio-material actor-networks ${ }^{2}$, in which neither actors nor relations between

130 them are assumed to begin with. Instead a central concern of assemblage thinking is to

131 attend to the "on-going labour of bringing disparate elements together and forging

132 connections between them" (Li 2007, 263). So to talk of assemblage is to talk of assembling

133 through labors, material practices, friction and accommodation (Swanton 2013). The city

134 thus emerges from multiplicity in fragmented, unpredictable and asymmetrical ways

135 (Bender 2010).

137 Repositioning the city as processually produced and always becoming, assemblage thinking

138 reanimates the urban. It achieves this too by insisting that the social is not the only source of

139 action or basis for explanation; rather, assemblage locates human and nonhuman in the

140 same field of observation and explanation (Jacobs et al 2007; Farías 2010; Farber 2014). If

141 something has effect or initiates action, it is considered an actant imbued with agency: not

142 in a reflective sense but because of its capacity to make a difference though creative or

143 destructive capabilities (Latour 2005; Müller 2015a). Broadening the scope of agency makes

144 visible across the city a host of "unexpected practices from surprising angles" (Farber 2014,

145 133). Furthermore, assemblage thinking suggests that, while any actor or entity in the urban

146 assemblage may be conditioned by the way it is related to others in an assemblage, it is not

147 fully determined by those relationships. Actors retain their autonomy and can be "detached

148 and plugged into" different assemblages where interactions change and actors' knowable

149 properties can be repurposed to release different and unpredictable 'capacities' by virtue of

150 what they act in relation with in practice (McFarlane 2011a, 653). Together, then, the

151 laboring of assemblage and distributed agency suggest the irreducible possibility that the

152 city might be changed in unpredictable ways to be assembled otherwise (see Anderson et al

153 2012, 172; Grove and Pugh 2015).

155 Assemblage thinking, then, seeks to explain the urban through mapping encounters and 156 practices through which the heterogeneous elements constituting the city are assembled. In 157 this sense, everything that matters to the assemblage is related to it in some way and the

\footnotetext{
2 The synergies between the language and conceptual bases of Assemblage Theory and Actor-Network Theory are frequently commented upon. While there are points of distinction between the sets of theories (Anderson et al 2012) they are often drawn on in tandem and assemblage is taken as a close equivalent of the actornetwork (Müller 2015a; 2015b).
} 
ways in which "everyday life... and larger shifts in political economy" are linked can be traced

159 without recourse to a division of the social into macro/micro, near/far, structure/agency

160 dualities (Anderson and McFarlane 2012, 124; Ureta 2014). No aspect of the city's socio-

161 spatiality can be explained as the contingent articulation of larger macro-structures or extra-

162 local forces. Rather, assemblage thinking's anti-reductionism locates all on the same

163 analytical plane to reveal how urban assemblages are "stitched into place by fragmented,

164 multi-scaled and multi-sited networks of association" (Jacobs 20063 ). The "wider systems of

165 relations' and 'structures' in which the city is entangled become part of how its coherence is

166 made, without being ascribed in advance as abstractions with ordering force. Yet

167 assemblage thinking remains critically alert to the obduracy of particular orderings as

168 relations are stabilised and scripted into urban performances such that differences become

169 bounded and the margins for manoeuvre around interactions and identities become

170 prescribed (Acuto 2011). Thus the potential to actualise different and unpredicted urban

171 trajectories is not unconstrained. Far from it. All possible trajectories are embedded in

172 contextual materialisations of socio-economic processes that have contingently produced

173 uneven relations and resources of power. Indeed, assemblage thinking keeps power to the

174 fore by recognising assemblages as "structured, hierarchized, and narrativised through

175 profoundly unequal relations of power, resource and knowledge" (McFarlane 2011c, 655;

176 Ureta 2014, Müller 2015a).

178 Of course, the idea of thinking the city through assemblage has been critiqued, often by 179 those concerned with the nature and political effectiveness of critical urban studies. Tonkiss 180 (2011), Brenner et al (2011) and Wachsmuth et al (2011), for example, have parsed careful 181 critiques of assemblage's theoretical coherence founded on the fluidity inferred by the 182 processual becoming of the city; the rejection of linear causality and notions of pre-formed

183 'structural' bases to urban processes and socio-spatial formation; and the rejection of 184 abstraction in favor of empirical detail. Others have raised concerns about the potential for 185 empirical complexity to overwhelm analysis; the equivalence of human agency and the

186 effectivity of matter implied by distributed agency; the capacity to differentiate actors and 187 networks in terms of their relative power and significance; and whether assemblage seeks 188 primarily to understand how the urban is made, rather than how it can be made differently 189 (see Rankin, 2011; Graham 2010). 
191 We see many of the above critiques, however, as arising from particular applications of

192 assemblage rather than being inherent to its theorization of the urban. In what follows, we 193 present a brief assemblage account of urban regeneration in Newcastle, NSW before 194 working through four specific attributes of assemblage in terms of their potential for 195 rethinking urban regeneration to expand its conception both critically and generatively.

\section{Assembling urban regeneration in Newcastle, NSW}

198 Following assemblage's methodological insistence on starting from empirical detail 199 (Brownhill 2013; McFarlane 2011b), our work on assembling regeneration in inner 200 Newcastle has traced the material practices of actors from state and local government 201 bodies, developers, special purpose taskforces, bureaucrats, consultants and facilitators, 202 business associations, not-for-profits, media, residents, artists, community groups, public 203 transport and cycling advocates, and Indigenous groups. We have traced the role of the 204 non-human from standards, modelling and funding formulae, heritage and architecture, maps of sites under-mined by historic mining shafts and grouting used to render undermined sites developable, and visualisations of a 'renewed Newcastle' circulated through public consultations, reports and strategy documents. We have observed practices from strategic planning and development, securing planning approvals, decision making around public infrastructure dis/investments, public consultation, visioning events and workshops, protest and lobbying, to negotiating, enabling temporary occupation of vacant

211 commercial sites, and a multitude of small scale community and private sector-led 'place-

212 making' activities. We have traced the constitution and contestation of central regeneration

213 concepts such as livability, sustainability, decline and renewal and their differential

214 discursive mobilisation and material rendering by differently located actors.

216 The accounts we are producing are unpacking the labours, negotiations and settlements 217 involved in creating and maintaining relationships of authority between the NSW state 218 planning and transport authorities, UrbanGrowth (NSW government urban regeneration 219 body), Newcastle City Council, Hunter Development Corporation (regional economic 220 development body), Newcastle Now (Business Improvement Association) and GPT, a 221 largescale developer at the heart of plans to redevelop major sites along inner Newcastle's 
main thoroughfare, Hunter St. They are revealing how existing hierarchies, distributions of resources and knowledge, have secured core decisions around planning and infrastructure investments/disinvestments in the city: notably to remove the city's heavy rail line, in face of strident public disquiet, to allow the release of land with rich development potential

226 (Ruming et al 2016) and to approve a major GPT/UrbanGrowth high-rise redevelopment

227 project on Hunter St. Yet they are also revealing the assembling of actors and practices that have enlivened quite a different regeneration trajectory and vision for the city. They explore how GPT and UrbanGrowth have negotiated with Renew Newcastle-a non-for-profit dedicated to finding short and medium term uses for vacant buildings in Newcastle's CBDto allow access to city-centre premises by small scale ventures by small businesses, artists, retailers, community-based organisations that have effectively rematerialized the inner city and its affective resonances. The success of these ventures in drawing people into the city centre is connected to a multiplicity of 'placemaking' projects, many co-funded by Newcastle City Council, which have transformed small spaces in the city through street furniture, graffiti and artworks, community gardens, temporary cultural uses and events. Together these have produced both an new affective experience and, in a counteractualisation

238 (Lagendijk et al 2014), a groundswell of support for a smallscale, piecemeal variety of 239 'regeneration' that can coexist with the city's existing built environment of heritage listed, low rise buildings. This support took material form in NICRA, a group formed to lobby-using

241 affective material strategies (see Figure 1)-for a low-rise, heritage-sensitive form of 242 regeneration. At the time of writing, the GPT/UrbanGrowth proposal had just been 243 redesigned, with much reduced commercial space and building heights, restored street level 244 shops, cafes and public space. Meanwhile, in the same week, the work began on physically 245 removing the city's heavy rail line and debate continues on what role the released land will play in the ongoing assemblage of a regenerated Newcastle.

\section{Assembling urban regeneration: capacities for critical and generative rethinking?}

249 Our account above is informed by four distinctive analytical capacities of an assemblage lens 250 that allow regeneration to be conceptualised as a diversely constituted practice enacted in 251 everyday materiality, as well as discursively and ideologically, and as produced through 252 multiscalar relations that need to be configured, negotiated and stabilized across an array of 253 social and material, authoritative and non-authoritative domains. These capacities make 
254 known the variety of forces and relations at work to make urban regeneration possible, the 255 excess of capacities and multiple trajectories this generates and, crucially, the ways these 256 trajectories may be constrained.

\section{(1) Revealing the relational, multiple and processual nature of urban regeneration}

259 Assemblage understands the urban-and hence its regeneration-as multiplex (Farías 2011, 369; O'Callaghan 2012). Interlocking multiplex processes operate simultaneously to regenerate the city: eg developing land and buildings; providing and maintaining infrastructure; shaping political identities and interests; fashioning and participating in political processes; governing social behaviour and engaging with the city economically, socially and culturally. These processes can interact and transform each other. They can work in counterpoint and to multiple timelines (eg largescale state-led mega projects vs smallscale incremental placemaking practices) (O'Callaghan 2012). Moreover, they involve their own modes of ordering that circulate simultaneously and are composed of diverse socio-materialities. Consider the actors, devices, materials and social practices drawn into relation in regenerating the urban built environment: developers, architects, heritage advisors, media, engineers, builders, bureaucrats, planners, residents, politicians, materials standards, building codes, environmental regulations, geotechnical reports, strategy and planning documents, concrete, glass and steel, designing, strategising, negotiating, planning,

273 promoting, consulting. The diverse assemblages these constitute cannot be reduced to any

274 single logic, temporality or spatiality (Fuller 2013).

The implications of assemblage's orientation to relationality, multiplexity and processuality

277 for accounts of urban regeneration are profound. Conventional analyses have tended to be restricted to a limited array of processes thought to be central to structuring social relations

279 of dis/investment; strategic visioning and policy making; political decision making; land and

280 building redevelopment processes; and the operation of related power relations, social 281 realignments and dislocations. This risks subsuming the multiplexity, multiplicity of entities 282 and socio-material practices that are assembled and associated to enable regeneration

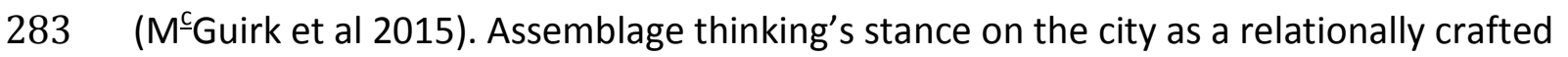
284 multiplex informs its exploratory style of inquiry that works empirically from the ground up, 285 rather than as a form of critique guided in the first instance by theoretical abstractions 
286 (Farías 2011). Figured as such, urban regeneration becomes the contingent achievement of

287 socio-material processes and specific, concrete and differentially sedimented relations

288 between diverse entities that iteratively and cumulatively shape regeneration trajectories

289 (Swanton 2013; O’Callaghan 2012). Regeneration becomes an ongoing event potentially

290 assuming multiple forms and multiple points of determination (Farías 2011; Jacobs 2006).

\section{(2) Revealing the multiscalar labouring involved in the (socio-material) assembling}

\section{3 that constitutes urban regeneration}

294 Assemblage's focus on the labours of assembling demands a baroque understanding that embraces the empirical messiness and complexity of phenomena (Jacobs 2006). This ethos repositions conventional appeals in critical urban studies to (i) abstraction (ii) articulations of 'micro' and 'macro' factors and (iii) singular logics of causality, in ways that lay the ground for reconceptualising the nature and potential trajectories of regeneration.

Resisting abstraction: Rather than seeking social-structural explanations of regeneration related to the dynamics of capitalist dis/investment flows, urban restructuring, or the political projects of neoliberalism, assemblage has us approach these processes from within, through exploration of the variegated practices and processes of 'how things happen' as regeneration is achieved (Farber 2014; McFarlane 2011b). Tracing 'how things happen' deals with the 'difficulty of things' (Dovey 2010, 348) without relying on abstract conceptions of processes (eg capitalist investment imperatives) or pre-formed social categories (eg state or private sector) that can occlude attention to process and practice prior to their investigation (Acuto 2011, Müller 2015a). 'Investment imperatives', 'commodification of place' or the actions of 'the state' cannot be explained as the outcomes of underlying or essential logics of capitalism or neoliberalism, but only as effects of "socio-material processes; as contingent

311 achievements enacted in particular sites" (Swanton 2013, 284). While these conceptions

312 and categories themselves remain useful, they function in assemblage as reflexive heuristic

313 devices whose contextual constitution has to be "studied as they operate in the world"

314 revealing "the work of connection" necessary for them to be effective (Tsing 2011, 6).

315 Assemblage thinking both unsettles processes and categories traditionally foregrounded in

316 critical analyses of regeneration and expands the array of constituent practices taken into

317 account. Simone (2011), for instance, suggests that processes of domination, 
commodification and dispossession-abstractions commonly invoked to critique the power relations and outcomes of regeneration-might be extended to consider the workings of the iterative, collaborative and adaptive to reveal regenerations' dynamics and multiple negotiations.

Resisting micro/macro binary articulations: In conventional critical regeneration analyses, abstraction is closely related to the analytical move of interpreting local conditions in terms of macro forces and extra-local determinations that fashion outcomes as contingent articulations of wider processes and structures. Comparatively, assemblage blurs the division of the social such 'macro-structures' or 'extra-local forces' are not separable but must be understood as part of the relations and dynamics that produce regeneration across multiscaled practices (Farías 2011). This demands a focus on particular sites through which regeneration assemblages are composed and enacted, connecting across sites and scales:

331 for example, creating knowledge through expert reports sourced from global consultants;

332 engaging communities in small-scale placemaking projects to enhance material landscapes;

333 attracting development corporation investments in built environment projects; designing 334 and enacting financial incentive schemes. This focus opens out analysis to incorporate the 335 multiple scales and temporalities across which labours of assembling occur.

In addition, the focus on labouring foregrounds ongoing, negotiated socio-material practices

338 through which regeneration assemblages are composed by relating materialities,

339 technologies, objects, natures and humans (Farías 2010, 13): for instance, circulating

340 imagery of a regenerated 'future city'; rehearsing performative routines of consultation

341 between authoritative regeneration actors and community members; engaging residents in

342 the emergent socialities of regenerated landscapes. Accounting for the labours needed to

343 shape and enact particular kinds of regeneration can be uncovered through this focus,

344 bringing in the 'forgotten many' (Jacobs 2006) of the affiliations that form around

345 regeneration processes to give it the appearance of coherence. Excavating this laborious

346 assemblage attends to an array of multi-scaled socio-material practices that reveal the

347 claims made of urban regeneration, how these claims materialize, and how they harness

348 other processes in order for regeneration to take on specific forms and functions. 
In these ways, assemblage thinking speaks to power geometries articulated at multiple,

351 intertwined scales and to specific socio-materialities as they translate in particular urban

352 sites and practices that enable regeneration (Acuto 2011). Critically, this allows us to observe 353 how urban regeneration is written into 'big stories' - of globalisation, urbanisation, capitalist 354 development, neoliberalisation-by tracing chains of meaning and practice that are pieced 355 together in situated encounters, whereby 'wider processes' become practically effective by 356 being mobilised to appear as universals that frame the practice of power. It also allows us to 357 capture the negotiations, collaborations and compromises - the 'frictions' - these generate 358 in place, as well as the new alignments (including in culture and power) and the 'structures 359 of confinement' and opportunity these produce (Tsing 2011).

Resisting singular logics of causality:

362 Assemblage's lack of reliance on abstractions or scaled ideas of a priori 'structuring' macro 363 processes means that causal or determining power cannot straightforwardly be ascribed to 364 given 'structures', scaled political economic orderings or social categories (such as 'the state'). These are repositioned instead as mediated socio-material achievements made in differential enactments. And these enactments are performed in overdetermined contexts shaped through "deeply unequal relations of power, historical traces... practices of routine, struggle and improvisation within particular sites" (McFarlane 2011a, 386). Assemblage, then, has us examine how causality is realised, in place, through relational configuration and recognizes that "the creative reworking of relations in motion may render causality multiple and indeterminate" (Anderson et al 2012, 183). This does not deny causal power to actors,

372 though it insists that this cannot be pre-determined (Cupples 2011). Applying this

373 understanding allows for critical and generative analysis of regeneration, capable of 374 exploring how its situated assembling mediates 'broader' socio-economic processes (global 375 competition, neoliberal urban governance) and, simultaneously, generates its own causal 376 powers to enact different forms of agency and generate different realisations of processes 377 (domination, adaptation, negotiation) (McFarlane, 2011c). Assemblage thinking's insistent

378 focus on specific sites of practice and the labours of composition underlies a fluid and 379 unfinished conception of regeneration as always in-the-making. 
382 A focus on the labours of composition focuses on how urban regeneration assemblages are

383 ordered and stabilised but, equally, with how composition might entail unpredictable

384 change and reassembly. An entity may be "plugged into" a different assembly such that its 385 knowable properties are productive of different capacities. For instance, a policy document 386 staking claims to the livability of regenerated spaces might be mobilised by developers to 387 advance high-density transit-oriented development or, alternatively, by local communities to advocate nurturing local architectural qualities and medium-density streetscapes (Kraftl 2014). Assemblage can thus open out the multitude of possible capacities realized in enacting regeneration, though these are only realised within particular confederations in which urban subjects and objects can perform in multiple ways depending on the sociotechnical networks and sets of practices involved (Farías 2011, Grove and Pugh 2015).

393 Through this register of thinking, regeneration can be reconceived as a series of relational 394 sites of "doing, performance and events...subject to material, performative and discursive 395 change through relational processes, such as new actors infringing on existing formations" 396 (McFarlane 2009, 562). Remove or lose one entity from an assemblage or add another and the structure of possibilities changes as each new alliance unleashes unpredictable associations and previously under-tapped capacities. Through such shifts, stabilised relations might be reinscribed in meaning and function and actors can take on different social/political attributes (eg politicians or community leaders; council meetings; transit systems; consultation sessions) (see Jacobs et al 2007, Cupples 2011).

These aspects of assemblage thinking open up more careful consideration of the constitutive, generative, reiterative and (potentially) transformative associations of regeneration insofar as what regeneration can be/come is never fully stable or wellbounded. Its elements are multiple, its capacities are immanent, contingent and emergent

407 (Ruddick 2012) and so its trajectories are never fully settled but always open to the 408 possibility of reordering associations, and hence capacities, to create dynamic potential for 409 innovation, novelty and differentiation (Allen and Cochrane; 2010; Jacobs 2012).

410 Assemblages of urban regeneration need to be viewed, to paraphrase O'Callaghan (2012, 411 1937), as one potential trajectory that also incorporates multiple other trajectories and 412 possibilities. 
414 This assemblage-inspired reconceptualisation of regeneration provides analysts a capacity to

415 explore how received, sedimented relations (from property relations to affective resonances

416 between human actors and specific built landscapes) might be enacted differently. As

417 Suchman says $(2012,57-58)$, it can "reanimate the figures that populate our socio-material

418 imaginaries and practices, to examine the relations that they hold in place and the labours

419 that sustain them, and to articulate the material semiotic reconfigurations required for their

420 transformations". A further step in reanimation lies in bringing into view the nonhuman

421 capacity for agency; for instance, the potential for materials to force an assemblage out of

422 its current configuration and to "jump into trajectories that are neither foreseeable nor

423 controllable" (Henry and Roche 2013). We might consider, for instance, how the material

424 characteristics of a regeneration site-soil qualities, flood liability, construction materials, or

425 the resonances of its built environment with particular cultural affinities-do particular kinds

426 of work to ignite certain regeneration possibilities, constrict others or take unanticipated

427 directions (Harris 2013). Similarly, we might consider the capacity of particular visualisation

428 devices to trigger affective community claims in support or opposition to particular visions of

429 regeneration. This wider prism can account for the diversity of forces at work by making

430 visible the various human and non-human alliances that create regeneration. But it also

431 allows the complexity of processes involved, as these alliances connect the embodied,

432 technical, practical and affective become available for analysis (Jacobs 2008). Such analysis is

433 resourced by assemblage thinking to traverse categorical boundaries (human/artifact,

434 social/natural) and to prise open processes, categories and blackboxed accounts of their

435 dynamics (Acuto 2011; Müller 2015a). Thus it can foreground the ontological possibilities of

436 multiple trajectories and indeed the potential for particular alternatives.

(4) Providing critical insights into how urban regeneration trajectories are constrained

439 Assemblage's capacity to explore the potential for regeneration trajectories to be unsettled

440 is highly productive and underpins a generative politics. Yet its equal orientation towards the

441 obduracy of particular orderings provides crucial insights for exploring how multiple

442 potential trajectories of regeneration assemblages are constrained as powerful forces

443 "caricature, restrain, restrict and police other objects" (Shaw 2012, 623) such that only

444 "certain common projects....become visible and sayable" (Gidwani 2008, 101), certain actors

445 accrue hegemonic status capable of defining and structuring relations, and certain urban 
assemblages get to hold together (Ureta 2014; Fuller 2013). Yet the practice of power relations is not simple. Different agents within an assemblage possess different resources and capacities to act, but these do not straightforwardly translate into power. Rather, power relations are "a performative work in progress...(shaped) through interactions with other nonhumans, human bodies, institutions, emotions, discourses, and ideas and through the overlapping of different networks" (Cupples 2011, 940). Hegemonic actors-from global development corporations to state authorities-or ideologies-from neoliberalism to creative cities - therefore become (or remain) powerful through situated material-semiotic and performative configurations.

455

So assemblage accounts of urban regeneration fully recognise the effects of power, but explore it through ethnographies of power geometries wherein that power is assembled in practice (Acuto 2011, 256, Bender 2010). Such analyses resist preconfiguring the power relations of a particular assemblage, but are poised instead to reveal how some actors become capable of problematizing, mobilising and enrolling actants such that distinctive geometries unfold across the socio-material and across articulations of the 'macro/micro'. They might trace how, for instance, global formulae for developer profit ratios are associated with floor space ratios in land use zones in regeneration masterplans, how these are represented in vizualisations that attempt to shape orders of value about future regenerated urban landscapes, and how these vizualisations affectively resonate with differentiated local communities' conceptions of worth, or are subverted by them as culturally implausible (Farber 2014). Power, then, is an achievement that must be, and often can be, reasserted through the complex coordination of socio-material practices (Ureta 2014). Assemblage provides refined means for excavating the mechanics of power behind regeneration, revealing empirically how sedimentation, repetition, habit and hierarchised

471 relations are materialised to enhance or restrict the capacity of certain regeneration 472 trajectories.

474 Exploring how urban regeneration trajectories reflect the reproduction of enduring political475 economic power hierarchies, the replay of habitual resource distributions, and the 476 reassertion of socio-material orderings, is both critical and generative. It reveals the 477 relational, socio-material dynamics wherein certain capacities and trajectories are prevented 
478 from being activated. As Shaw $(2012,621)$, puts it "worlds are ... for the most part stable and 479 do not exhibit monstrous contingency...the world is stabilised, anchored". Applied to urban 480 regeneration, assemblage analytics provide insight into the forging of such anchorings in 481 situated encounters where 'wider processes' are translated through negotiations, 482 collaborations and compromises. They excavate how the 'frictions' in place forge "structures 483 of confinement...(that) inflect historical trajectories, enabling, excluding and particularizing" 484 (Tsing 2011, 6). While assemblage analytics refuse to attribute the obduracy of particular assemblages to linear causality and determination (Fuller 2013) they reveal assemblages as arrangements that "create agents...allowing us to trace relationships of domination as they are dynamically established" (Caliskan and Callon 2010, 8-9) ${ }^{3}$. This insight reveals how 'structural processes' are shaped through obduracy and enabled to repeatedly 'stitch in' patterns of outcomes (Jacobs 2008).

'Structures of confinements' in urban regeneration are difficult to unpick as they shape new interests, identities and trajectories that are differentially beneficial. Assemblage analyses' excavation of the relational, socio-material dynamics behind this formation unsettle categories, processes and hierarchies, questioning their naturalisation as hegemonic, and opening them out as potential points of political intervention, revealing contingency and possibilities for reassembly (Müller 2015a). For our purposes, this is a key capability for a critical and generative rethinking of urban regeneration, sensitizing us to the means by which potential trajectories are channeled and contained. Assemblage thinking allows us to recognize both potentialities and vulnerabilities, and where these are closed down via particular materialisations of power and inequality in which not all potential outcomes are equally possible (Ureta 2014, Müller 2015a).

502

\section{Conclusion}

504 As assemblage thinking has become widespread in human geography, debate has 505 proliferated about its workings and worth. Our gravitation towards assemblage is informed 506 by a commitment to reconceptualising urban regeneration to advance critical and generative

\footnotetext{
${ }^{3} \mathrm{Li}(2007,270)$ points out that assemblages "cannot be resolved into neat binaries that separate power from resistance, or progressive forces from reactionary ones. It is difficult to determine who has been co-opted and who betrayed. Fuzziness, adjustment and compromise are critical to holding assemblages together".
} 
accounts. Assemblage-inspired research provides a political edge in taking us beyond

508 hegemonic categories of powerful actors, structured notions of power relations and

509 'universals' such as globalisation, competitive urbanism and market forces as drivers of regeneration (Müller 2015a). It questions the naturalisation of these categories and forces.

511 Rather than seek to expose this naturalisation through critical deconstruction, it aims to lay

512 out contingent assembly and reveal the conduits that provide stability and unity to

513 hegemonic assemblages by mapping the socio-material creation of categories, frames and

514 structures and rendering them open to political challenge. As Bender (2010, 3005-6) argues,

515 "if the actornetwork is a multiplication of the number of actors then there is also an increase

516 in the number of contingencies and points of potential intervention thus increasing

517 opportunities for responsible action". This is central to the critical and generative capacities

518 of assemblage accounts of regeneration to enliven our sense of its possible pathways and

519 take hold of the politics that reside within (Shaw 2012, Anderson et al 2012).

521 So assemblage points urban regeneration analysts to the possibilities of its processes to 522 engender outcomes other than the systematic regressive redistribution of wealth and 523 power, extension of private property rights, and creation of exclusionary, gentrified urban 524 landscapes. It provides conceptual mechanisms - most particularly those examined here525 that enable the reconception of actually existing urban regeneration to expose the 526 constitution of its trajectories and "to search out new vantage points (and) make operative 527 undiscovered capacities that are latent" (Ruddick 2012, 211). These conceptual mechanisms 528 reveal how institutional processes that govern regeneration (eg masterplanning, public 529 consultation, public private partnerships) - while they might reflect extant power relations in 530 their attempts to achieve certain strategic purposes and craft particular urban subjects and 531 materialities - cannot fully determine outcomes. Nor can they fully contain the potential for 532 entities to slip out and become aligned with other configurations, overlap with other 533 processes, suggest different identities, trigger other events or create unpredicted capacities 534 that destabilise imagined trajectories (Grove and Pugh 2015). Furthermore, assemblage's 535 recognition of materiality and its agentic capacities opens out the array of actants and forces 536 thought capable of animating regeneration outcomes. Without pre-emptively falling back on 537 existing categories of analysis or purely instrumental understandings of material, it allows 538 for the capacities of 'things', technical devices or material practices to open up new objects 
and sites of politics and to transform the issues and claims that can be bound to regeneration or contested around it (such as collabaration, decommodification, commoning). These take us beyond the hegemonic actors and forces habitually recognised and enable us to recognise the emergent and the potential in new animating objects, new juxtapositions, new capacities and new knowledges of regeneration (Müller 2015a).

This is not an analytics of assemblage bereft of politics (Jacobs 2012) but an explicitly strategic and politicised assemblage thinking that might inform strategic forms of assembling aimed to counter attempts to govern for particular interests and arrangements of power that prevent movement towards more 'emancipatory assemblages' (Ruddick 2012). This might take the form of tracing instances where outcomes are progressive and where power flows change, and articulating the socio-material practices and relational workings involved including the settlements reached between informal actors and those in nominally hegemonic roles. Insofar as we can intentionally control the agentic cuts our academic interventions actually achieve once they are in circulation (Greenhough 2012), assemblageinspired accounts can resource strategic knowledge production to be put to work to galvanise and inform strategic action by various publics (activist, community, governmental, hybrid) that seek transformative engagements to enliven alternative trajectories of regeneration and to advance political and material strategies to stabilise these attempts

558 (Bender 2010; Russell et al 2011). In this way, assemblage-inspired accounts can resource

559 bringing people, things and knowledge together to energise the purposive creation of urban regeneration assemblages aimed to claim authority in the fields of decision-making that shape urban regeneration and it possibilities (Müller 2015b, Iveson 2013).

\section{References}

567 Acuto, M. (2011) Putting ANTs into the mille-feuille City 15 (1), pp.552-562.

568 Allen, J. and Cochrane, A. (2007) Beyond the territorial fix: regional assemblages,

569 politics and power Regional Studies, 41 (9), pp. 1161-1175.

570 Allen, J. and Cochrane, A. (2010) Assemblages of state power: topological shifts in the

571 organization of government and politics Antipode 42 (5), pp. 1071-1089.

572 Anderson B. and McFarlane, C. (2012) Assemblage and geography Area 43 (2) pp124-127. 
Anderson, B., Kearnes, M., McFarlane, C. and Swanton, D. (2012) On assemblages and geography Dialogues in Human Geography 2 (2), pp. 171-189.

Bender, T 2010 Postscript: reassembling the city: networks and urban imaginaries. In: Farías, I. and Bender, T. (eds) Urban assemblages: how actor-network theory changes urban studies, London: Routledge, 303-323.

Brenner, N. and Theodore, N. (2002) Cities and the geographies of 'actually existing neoliberalism'. In: Brenner, N. and Theodore, N. (eds) Spaces of neoliberalism: urban restructuring in North America and Western Europe. Oxford: Blackwell, 2-32.

Brenner, N., Madden, D, J. and Wachsmuth, D. (2011) Assemblage urbanism and the challenges of critical urban theory City 15 (2), pp. $225-240$.

Brownhill, S. (2013) Just add water: waterfront regeneration as a global phenomenon. In: M. Leary and J. McCarty, The Routledge companion to urban regeneration, London: Routledge, 45-55.

Caliskan, K. and Callon, M. (2010) Economization, part 2: a research programme for the study of markets', Economy and Society 39 (1), pp. 1-32.

Cochrane, A. (2007) Understanding Urban Policy: A Critical Approach. Oxford: Blackwell. Cupples, J. (2010) Shifting networks of power in Nicaragua: relational materialisms in the consumption of privatized electricity Annals of the Association of American Geographers 101 (4), pp. 939-948.

Delanda, M. (2006) A New Philosophy of Society, New York: Continuum.

Dovey, K. (2010) Becoming Places, London: Routledge.

Farber, A. (2014) Low-budget Berlin: towards an understanding of low-budget urbanity as assemblage Cambridge Journal of Regions, Economy and Society, 7, pp.119-136.

Farías, I. (2010) Introduction: decentering the object of urban studies. In: Farías I. and Bender T. (eds) Urban assemblages: how actor-network theory changes urban studies, London: Routledge, pp. 1-24.

Farías (2011): The politics of urban assemblages, City 15 (3-4), pp. 365-374.

Fuller, C. (2013) Urban politics and the social practices of critique and justification: conceptual insights from French pragmatism, Progress in Human Geography 37 (5), pp. 639-657.

Gidwani, V. (2008) Capital interrupted: agrarian development and the politics of work in India. Minneapolis MN: University of Minnesota Press.

Greenhough, B. (2012) On the agencement of the academic geographer Dialogues in Human Geography 2 (2) pp. 202-206.

Graham, S. (2010 Interview with Stephen Graham. In: Farías I. and Bender T. (eds) Urban assemblages: how actor-network theory changes urban studies, London: Routledge, pp. 197-203.

Grove, K. and Pugh, J. (2015) Assemblage thinking and participatory development: potentiality, ethics, biopolitics, Geography Compass, 9 (1), pp. 1-13.

Hall, T. and Hubbard, P. (Eds) (1998) The entrepreneurial city: geographies of politics, regime and representation. Chicester: John Wiley \& Sons. 
Harris, A. (2013) Concrete geographies: assembling global Mumbai through transport infrastructure, City, 17 (3), pp. 343-360.

Henry, M. and Roche, M. (2013) Valuing lively materialities: bio-economic assembling in the making of new meat futures, New Zealand Geographer 69 (3), pp. 197-207.

Iveson, K. (2013) Cities within the city: do-it-yourself urbanism and the right to the city, International Journal of Urban and Regional Research, 37 (3), pp. 941-56.

Jacobs, J.M. (2006) A geography of big things, Cultural Geography, 13, pp. 1-17.

Jacobs, J.M. (2008) Epilogue: requalifying the city. In: McGinn, P., Thompson, S. and Tonts, M. (eds) Qualitative urban analysis: an international perspective, Bradford: Emerald Insight, pp. 241-249.

Jacobs, J.M. (2012) Urban geographies I : Still thinking cities relationally, Progress in Human Geography, 36 (3), pp. 412-422.

Jacobs, J.M., Cairns, S and Strebel, I. (2007) A tall story...but a fact just the same; the Red Road high-rise as a black box, Urban Studies, 44 (3), pp. 609-629.

Kraftl, P. (2014) Liveability and urban architectures: mol(ecul)ar biopower and the 'becoming lively' of sustainable communities, Environment and Planning D, 32, pp. 274-92.

Latour, B. (2005) Reassembling the social: an introduction to actor-network-theory, Oxford and New York: Oxford University Press.

Lagendijk, A, Van Melik, R., De Hann, F., Ernste H, Ploegmakers, H. and Kayasu, K. (2014) Comparative approaches to gentrification: a research framework, Tidjschrift Voor Economische en Social Geografie, 105 (3), pp. 358-365.

Leary, M, and McCarty, J. (2013) The Routledge Companion to Urban Regeneration, London: Routledge.

Lees, L. 2012 The geography of gentrification, Progress in Human Geography, 36 (2), pp. 155171.

Legg, S. (2009) Of scales, networks and assemblages: the league of nations apparatus and the scalar sovereignty of the government of India Transactions of the Institute of British Geographers 34 (2), pp. 234-253.

$\mathrm{Li}, \mathrm{T} .2007$. Practices of assemblage and community forest management. Economy and Society 36 (2), pp. 263-293.

MacLeod, G. and Jones, M. (2011) Renewing urban politics Urban Studies, 48 (12), pp.2443 2471.

McCann, E. and Ward, K. (2011) Mobile Urbanism. Cities and Policymaking in a Global Age, Minneapolis: University of Minnesota

McFarlane, C. (2009) Translocal assemblages: space, power and social movement Geoforum 40 (4), pp. 561-567.

McFarlane, C. (2011a) On context I 15 (3-4), pp. 375-388.

McFarlane, C. (2011b) Assemblage and critical urbanism City 15 (2), pp. 204-224.

McFarlane, C. (2011c) The city as assemblage: dwelling and urban space Environment and Planning D: Society and Space 29 (4), pp. 649-671. 
654

655

656

657

658

659

660

661

662

663

664

665

666

667

668

669

670

671

672

673

674

675

676

677

678

679

680

681

682

683

684

685

686

687

688

689

690

691

692

693

694

$M^{c}$ Guirk, P.M. (2004) State, strategy and scale in the competitive city: a neo-Gramscian analysis of the governance of 'global Sydney'. Environment and Planning A 36 (6), pp. 1019-1043.

$M \stackrel{\complement}{-}$ Guirk, P.M. Bulkeley H and Dowling, R, (2015), Configuring carbon governance in the city: Insights from Sydney, Australia, Annals of the Association of American Geographers DOI: 10.1080/00045608.2015.1084670

Müller, M. (2015a) Assemblages and actor- networks: rethinking socio-material power, politics and space, Geography Compass, 9 (1), pp. 27-41.

Müller, M. (2015b) A half-hearted romance? A diagnosis and agenda for the relationship between economic geography and actor-network theory (ANT) Progress in Human Geography, 39 (1), pp. 65-86.

O'Callaghan, C. (2012) Contrapuntal urbanisms: towards a postcolonial relational geography Environment and Planning A 44, pp.1930 - 1950.

Ponzini, D. and Rossi, U. (2010) Becoming a Creative City: the entrepreneurial mayor, network politics and the promise of an urban renaissance Urban Studies 47 (5), pp. 10371057.

Rankin, K.N. 2011 Assemblage and the politics of thick description, City 15 (5), pp. 563-569. Rossi, U. and Vanolo A. 2013 Regenerating what: the politics and geographies of actually existing regeneration. In: M. Leary and J. McCarty, The Routledge companion to urban regeneration, London: Routledge, 159-167.

Ruddick, S. 2012 Power and the problem of composition Dialogues in Human Geography 2 (2), pp.207-211.

Ruming, K., Mee, K.J. and M드난, P.M. (2016) Planned derailment for new urban futures? An actant network analysis of the "great [light] rail debate" in Newcastle, Australia. In: Y. Rydin and L. Tate (eds) Exploring the potential of Actant Network Theory, Routledge/Taylor \& Francis: London (in press).

Russell, B., Pusey, A. and Chatterton, P. (2011) What can an assemblage do? I, 15 (5), pp. 577-583.

Samara, T. R. (2010) Policing development: urban renewal as neo-liberal security strategy Urban Studies 47 (1), pp. 197 - 214.

Shaw, I. (2012) Towards an evental geography Progress in Human Geography 36 (5), pp. 613627.

Simone, A. 2011 (2011) The surfacing of urban life City 15 (5), pp. 355-364.

Smith, R. (2003) World city actor-networks Progress in Human Geography 27 (1), pp. 25-44. Suchman, L. (2012) Configuration. In: Lury, C. and Wakeford, N. (eds) Inventive methods: the happening of the social. Hoboken: Taylor and Francis, pp.48-60.

Swanton, D. (2013) The steel plant as assemblage Geoforum 44 pp. 282-291.

Tonkiss, F. (2011) Template urbanism City 15 (5), 584-588.

Tsing, A. (2011) Friction: An ethnography of global connection, Princeton University Press.

Ureta, S. (2014) The shelter that wasn't there: on the politics of co-ordinating multiple urban 
695 assemblages in Santiago, Chile Urban Studies 51(2) pp.231-246.

696 Wachsmuth, D, Madden D, Brenner, B. (2011) Between abstraction and complexity City 15 697 (6), pp. 740-750.

698 Ward, S. (2011) Port cities and the global exchanges of planning ideas. In: C. Hein (ed) Port 699 cities: Dynamic Landscapes and Global Networks, New York: Routledge, pp. 70-86.

700 
702 Figure 1. NICRA used balloons to simulate the height of proposed towers, counterposed 703 against the city's predominantly low rise built environment.

704

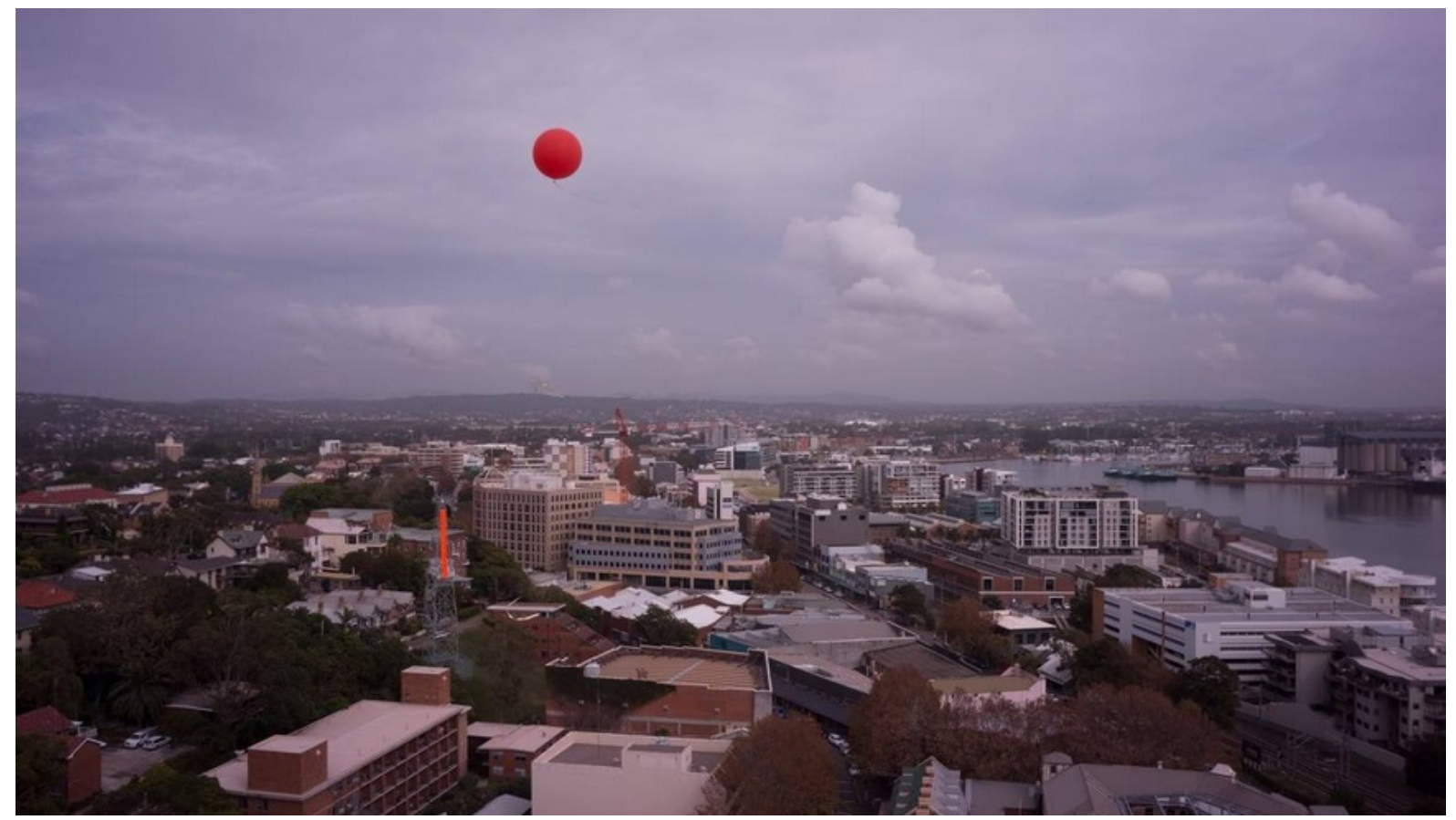

705 Source: Newcastle Herald

706

707 